p1267 Shades of
gray: How relevant
is race in biomedical
research?

\title{
Scientists turn anxious eyes to Bush's second term
}

Rarely have scientists felt they had so much at stake in a US presidential election. With George W. Bush about to embark on a second term in office, researchers who had pinned their hopes on Democratic challenger John Kerry are feeling stunned.

"The depression and anxiety over this is palpable," says John Gearhart, a stem cell researcher at Johns Hopkins University in Baltimore, Maryland.

Whether the issue is therapeutic cloning or AIDS policy, the Bush administration has repeatedly bumped up against accusations that it distorts scientific evidence for political ends.

A report issued in February by the Union of Concerned Scientists, a Washington, DC_-based pressure group, detailed dozens of cases in which scientific information appeared to have been suppressed for political purposes. It said the administration had altered reports and websites to remove information that ran counter to its policies on the environment, public health and arms control.

Dissatisfied with the administration's stance on science, a group of 48 Nobel Laureates declared their support for Bush's Democratic rival John Kerry.

Several key areas are likely to be watched closely by biomedical researchers in the president's second term. One is human embryonic stem cell research, which could unlock treatments for degenerative diseases like multiple sclerosis and Alzheimer disease. The president has opposed the creation of new embryonic stem cell lines, saying it requires the destruction of human embryos. Early in his first term he limited the use of federal funds to cell lines already in existence.

The 2 November results have drawn new battle lines in the stem cell debate. In an effort to sidestep the federal limitations, a group of scientists and private citizens in California placed a referendum on the state ballot authorizing $\$ 3$ billion in bond funds over 10 years for a new research institute devoted largely to embryonic stem cell work. The measure, known as Proposition 71, passed by a vote of $59 \%$ to $41 \%$, virtually guaranteeing California a starring role in stem cell research.

How the president will react to the measure remains to be seen. A bill to criminalize therapeutic cloning, which is likely to be important for developing stem cell therapies, has twice failed to pass the Senate. But a ban could still slip through as an attachment to another piece of must-pass legislation, such as an appropriations bill.

Some observers say they hope the White House will ignore the California initiative, or at least take a more moderate step, such as a loosening of federal restrictions that would allow the government to set its own ethical guidelines.

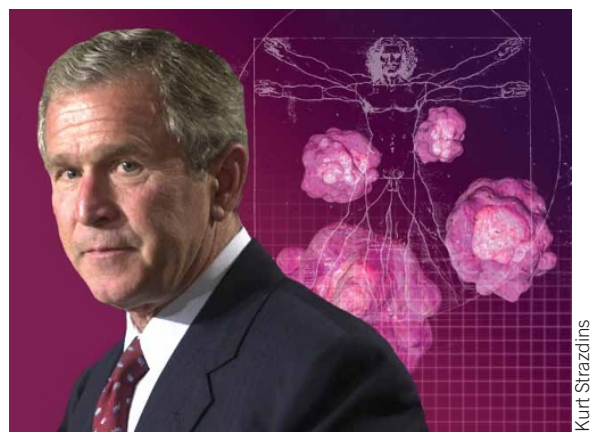

What will Bush's reelection mean for science?

In recent months, a number of prominent Republicans have spoken out in favor of the research. "It's too soon to say what the reaction will be," says Kevin Wilson, head spokesperson for the American Society for Cell Biology near Washington, DC. "But my feeling is that retribution is not likely."

But California may turn out to be part of a larger trend. New Jersey in May approved $\$ 50$ million for a state-supported embryonic stem cell research facility. Other states, fearing that their best and brightest will flee to where the money is, may also consider initiatives of their own. Washington state has already begun considering legislation to protect the legality of embryo research, and observers expect other states to follow suit.
Another contentious area is AIDS research. Bush made AIDS a cornerstone of his health policy when he pledged in 2003 to devote $\$ 15$ billion over five years to eradicating the disease worldwide. HIV researchers welcomed the announcement, but have since become disappointed that a portion of the money is earmarked for prevention programs emphasizing abstinence and monogamy over condom use. They point out that abstinence is often not an option for women in the parts of the world where AIDS is taking the heaviest toll (Nat. Med. 10, 759; 2004).

Sean Tipton, a spokesperson for the American Society for Reproductive Medicine, says biomedical researchers will also be watching Supreme Court nominations with bated breath, as Bush is likely to be able to choose between one and four new justices in his second term. The claim that scientific research is protected by the first amendment's guarantee of freedom of expression is considered an important last defense against proposed laws that would restrict some activities, such as therapeutic cloning. No one knows how the court would come down on the question today, but conservative appointees generally take a narrower view of first amendment protections. "It's an area of concern," says Tipton.

A key issue for many will be whether the existing backlog of visa applications can be resolved. Foreign researchers have found it much more difficult to enter the country because of policies aimed at keeping terrorists out. Many have simply given up: according to the most recent data, the number of foreign graduate students admitted to life sciences programs in the US has dropped by $19 \%$ (Nature 431, 231; 2004).

Bush said before the election that he was committed to reducing the visa backlog. Now that the people have spoken, he will have the chance.

Jonathan Knight, San Francisco

For more news and analysis go to news@nature.com www.nature.com/news 